Réthelyi, Mari. "Hungarian Jewish Stories of Origin: Samuel Kohn, the Khazar Connection and the Conquest of Hungary." Hungarian Cultural Studies. e-Journal of the American Hungarian Educators Association, Volume 14 (2021): http://ahea.pitt.edu DOI: 10.5195/ahea.2021.427

\title{
Hungarian Jewish Stories of Origin: Samuel Kohn, the Khazar Connection and the Conquest of Hungary
}

\author{
Mari Réthelyi
}

\begin{abstract}
At the turn of the twentieth century, the Khazar ancestry of European Jewry was a popular idea that particularly resonated throughout the discourse surrounding Hungary's national origin and belonging. One of this discourse's critical questions concerned whether Magyars and Jews were divided or united by ethnicity or religion: this paper demonstrates how Samuel Kohn (1841-1920), an important rabbi-scholar of the time, participated in this discussion by arguing for a common origin of the two groups. Kohn asserted that the Khazar ancestry of Hungarian Jews comprises both an ethnic and a religious connection. He considered two complementary questions: whether Hungarians and Jews possessed common ethnic origins and thereby belonged to the same race, and whether Magyars converted to Judaism during the Khazar era, i.e., the belief that Hungarians and Jews shared a common religion in the past. The contemporary political atmosphere magnified the significance of Kohn's contribution.
\end{abstract}

Keywords: Samuel Kohn, Khazars, nationalism, Hungarian conquest, Neolog Judaism, Orient, Jewish identity

Biography: Mari Réthelyi is an Assistant Professor of Religious Studies at Louisiana State University, Baton Rouge, LA, USA. She received her PhD in Jewish Studies at the University of Chicago in 2009. Her research interests include modern Hungarian Jewish history and literature, Jewish mysticism, Jewish race theories, Gender Studies, History of Nationalism, and Orientalism. She received the Steven Béla Várdy Legacy Scholarship from Helena History Press in 2020. mrethelyi @ lsu.edu

Nineteenth-century Hungarian scholars claimed that Hungarians were descended from Central Asians. Some of these scholars posited that, during the eighth and ninth centuries, the Hungarian tribes joined the Khazar tribes of the Russian Steppes and lived with them in the Khazar Empire, where many intermarried and converted to Judaism. This narrative of a common Khazar and Hungarian past became a popular theory that was asserted by several Hungarian scholars, including Jewish ones who ascribed the origins of most European Jews to this common past. The enduring nature of the Khazar ancestry theory about the kinship between Hungarians, Khazars and Jews can be seen in its impact upon later additions to the discourse, notably, Arthur Koestler's book The Thirteenth Tribe published in 1974. The extensive scholarly studies that followed this work and occupied the scholarly imagination attest to the lasting impact of this highly hypothetical theory. What most readers of Koestler might not know is that his claim in fact revives a theory that originated in late nineteenth-century Hungary, Koestler's country of 
Réthelyi, Mari. "Hungarian Jewish Stories of Origin: Samuel Kohn, the Khazar Connection and the Conquest of Hungary." Hungarian Cultural Studies. e-Journal of the American Hungarian Educators Association, Volume 14 (2021): http://ahea.pitt.edu DOI: 10.5195/ahea.2021.427

origin. This paper explores the Hungarian Jewish origins of this theory and its ideological, intellectual and historical context and implications.

The 1896 millennial celebration of the ninth-century Hungarian conquest served as an opportunity to emphasize Hungarians' right to rule over the region. The political message of the millennium celebration was that Hungarian leadership in the Carpathian Basin was historically justified and therefore beneficial for everyone (Gerö 2007; Gyurgyák 2007; Lafferton 2007). Since at the time the Hungarian nation was defined in terms of Hungarian speakers, the dominant form of Hungarian political nationalism encouraged Magyarization, an accommodating and liberal ideology which promoted the rapid assimilation of ethnic and linguistic minorities to the Hungarian majority through Hungarian language acquisition. The linguistic definition of nationhood justified Magyarization and promoted a rapid assimilation of the different minorities into the culture through language.

The Hungarian nationalist context created the possibility for Jews, a religious, linguistically-fluid community, to become ethnic Hungarians by acquiring the Hungarian language. Not all Jews responded in the same way to the possibility of Magyarization. In 1871, the community split into three groups: the anti-modernist Orthodox Jews who were mainly of Eastern European descent, the progressive Neolog Jews who were akin to the North American Conservative movement and generally originated from German and Czech territories and the traditionalist Jews referred to as status quo ante due to their decision to remain neutral in relation to the other two groups. Among the three denominations, it was the Neolog Jews who were the most eager to Magyarize. Moreover, in the 1880s, the Tiszaeszlár blood libel provided populist anti-Semitism with a platform for the national Anti-Semitic Party, a political party active from 1884-1895 that was established by Győző Istóczy (1842-1915). Anti-Semitic Hungarians questioned both the rights and place of Jews within the Hungarian nation, therefore the opportunity to convince the public that Jews were unequivocally Hungarian and could assimilate became a matter of urgency for the Neolog. The debates surrounding the place and rights of Jews in the Hungarian society led to culture wars in the early 1890 s which involved, first, the question of reception (legalization) of the Jewish religion and, second, the right to civil marriage that would give legal equality to the Jews. The law for civil marriage was passed in1894 and for religio recepta in 1895 , temporarily settling the question of integration. The pro-reception victory established a fortunate political environment for Neolog Magyarization. Neolog authors adopted contemporary Hungarian nationalist influences such as the fluid and inclusive understanding of ethnicity, the linguistic Magyarization movement, the emphasis on the Hungarian people's Central Asian Oriental origin and the historical emphasis on the conquest of Hungary.

The discourse surrounding the significance of the Hungarian Conquest combined the historical, linguistic and ethnological theorization of preconquest Hungarians. Hungarian scholars mapped out a historical migration route from the Hungarian people's Eastern home in the Khazar Empire to the honfoglalás ['conquest'] of the present land in the Carpathian Basin during the ninth century. They presented a number of contradictory positions that attempted to work out infinite variations regarding how Hungarians originated in the East. Ethnic kinships were "deciphered" by analyzing supposedly related languages. For example, the Turanian theory consisted of language analysis proving that Scythian was an Ugric language, and, thus, related to Hungarian. Other theories claimed that the various names found in different literary sources describing ancient central Asian peoples, such as Hun, Turkic, Hungarian, Iranian, and Scythian, actually all referred to the same nation and simply indicated different stages in the history of this 
Réthelyi, Mari. "Hungarian Jewish Stories of Origin: Samuel Kohn, the Khazar Connection and the Conquest of Hungary." Hungarian Cultural Studies. e-Journal of the American Hungarian Educators Association, Volume 14 (2021): http://ahea.pitt.edu DOI: 10.5195/ahea.2021.427

one nation. Since Hungarian nationalist historians claimed that Hungarians had non-European (Oriental) origins, the perceived Oriental origins of Jews cast them as aliens in other European countries. Yet in Hungary one of the ways in which Neolog Jews embraced Magyarization was by presenting themselves to the Hungarians as fellow Orientals. Arguments surrounding the presumed kinship between Hungarians and Jews were extensively published in the Neolog communal and scholarly journals, including the most popular form of this Oriental origin discourse, the Khazar ancestry theory, which asserted that Hungarian Jews were not ethnically Semitic but rather Hungarian.

Samuel Kohn (1841-1920) was a Neolog rabbi-scholar whose work investigated the ethnicity and religion of those present at the time of the Hungarian conquest. Kohn pioneered the historiography of Hungarian Jewry and received his doctorate from the Jewish Theological Seminary of Breslau in 1865, where he was a student of the influential Jewish historian Heinrich Graetz (1817-1891). In 1866 he became the rabbi of Pest and actively promoted the establishment of the Neolog Rabbinic Seminary in Budapest (founded in 1877) where he taught homiletics between 1899-1905. Kohn was the author who best articulated the Khazar ancestry theory, which posits an ethnic and/or religious connection between Jews and Hungarians due to their shared history during the Khazar Khanate in the Caucasus before the conquest of Hungary. Kohn combined multiple arguments exploring possible ethnic and religious connections between ancient Hungarians, Khazars, and Jews. To prove the presence of Jews among the conquering Hungarians, he circumvents the question of which theory is accurate by using Jewishness interchangeably to describe religious and ethnic affiliation. Kohn used the Khazar argument to elevate Judaism to an "original" religion of the Hungarians in order to promote indirectly the reception of Judaism as a national religion on par with Christianity. The dual nature of Kohn's argument is what gives the Khazar theory its power: Kohn used it to reason for both religious and ethnic historical connections. He claimed that, subsequently, no ethnic barriers exist between the Hungarians and Jews to prevent them from coexisting at present. Judaism was therefore presented as an equally adequate religion to Christianity and, indeed, a faith that Jews and Hungarians even used to share. No other origin hypothesis could provide religious as well as ethnic affiliations simultaneously. The ability to serve both purposes was paramount at the time when the Hungarian ethnic and national belonging of Jews was questioned due to anti-Semitism, and when the legalization (reception) of the Jewish religion was still an unsettled issue. Kohn's argument served as a plea for reception by showing the Hungarians' long engagement with Judaism dating back to the Khazar Empire, and that Hungarians and Jews conquered the land of Hungary together. The Khazar past narrative could not be made anywhere else in Europe due to lack of oriental identification and conquest stories.

In 1905, Kohn became chief rabbi of Budapest. The fact that he was an enthusiastic supporter of the Magyarization of the Neolog rabbinate (Schweitzer 1990; Schweitzer 2007) is evident in his works, such as Héber kútforrások és adatok Magyarország történetehez ['Hebrew Sources and Additions to the History of Hungary'], and Zsidó történelmi emlékek különös tekintettel Magyarországra ['Jewish Historical Monuments, With Particular Emphasis on Hungary'] that was released in 1896 as articles in the journal of the IMIT. These works were foundational in shaping the Neolog community's historical outlook. However, it is his $A$ zsidók története Magyarországon a kezdetektöl a mohácsi vészig ['The History of the Jews in Hungary from the Beginning until the Battle of Mohács'], published in 1884, that is his most significant exploration of Hungarian-Jewish connections via the Khazars. The same year, months before this book's publication, the Rabbinic Seminary's scholarly historical journal, the Magyar Zsidó 
Réthelyi, Mari. "Hungarian Jewish Stories of Origin: Samuel Kohn, the Khazar Connection and the Conquest of Hungary." Hungarian Cultural Studies. e-Journal of the American Hungarian Educators Association, Volume 14 (2021): http://ahea.pitt.edu DOI: 10.5195/ahea.2021.427

Szemle ['Hungarian Jewish Review'] published a shortened version of its chapter on the Khazars. In the same year, the communal popular weekly Egyenlöség ['Equality'] published the first part of this book in three installments, followed by the entire book in further installments, as well as revised editions of the book in 1900. The reception of Kohn's work was multi-faceted as Miklós Konrád (Konrád 2016) outlines in great detail. It became very popular and influential within Jewish circles, even though some respected Neolog intellectuals, such as the scholar-rabbi Sándor Büchler in his A zsidók története Budapesten a legrégebbi időktől 1867-ig ['The History of the Jews in Budapest Since the Beginning to 1867'] published in 1901, received it with skepticism. Kohn's theory was also not well received in Hungarian academic circles, as exemplified in the review by Gyula Nagy, a member of the Hungarian Academy of Sciences, in the journal, Századok ['Centuries'] (Nagy 1884). Nagy criticized not only the argument but also the methodology, and, thus, the scientific worth of Kohn's book.

Despite the book's failure in Hungarian academic circles, it was a breakthrough piece of scholarship because it set out to give a comprehensive narrative of Hungarian Jewry from the "beginning" of Hungarian history. The book retained its value despite the fact that Kohn never finished the second part of the history spanning the Battle of Mohács to the present. Kohn's work also established his version of the Khazar theory that represents a climax of apologetic historiography of Hungarian Jewry arguing for the acceptance of Jews into Hungarian society. He was not the first Jew to "invent" the Khazar theory, as Konrád (Konrád 2016) illustrates. The topic of the Khazar connection had been very popular for centuries in Jewish circles in both Hungary as well as other countries in Eastern Europe, as attested to by the multiple published translations and editions of The Kuzari - the apologetic book about the Jewish Khazars written by Yehuda Halevi in the twelfth century that in many ways originated the hypothesis (Shear 2008). However, even as in the nineteenth century the Jewish scholars discussed the Khazar roots of Eastern European Jewry (Brook 2003), it remained a singularly Jewish interest and was barely mentioned in non-Jewish Eastern European circles outside of Hungary and Russia (Shear 2008). As demonstrated by Peter Golden (Golden 2007), in Hungary it was a popular theory due to the Oriental historical narratives of Hungarian origin.

In order to establish the Oriental historical connection, linguistically focused Hungarian scholarship traced loan words between the Hungarian and Khazar languages (Róna-Tas 2007). Two foundational linguistic theories of Hungarian origins, Turkic and Finno-Ugric, developed in parallel. Some scholars claimed the Hungarian language was of Turkic origin (as the Khazar language was also believed to be), while others championed the Finno-Ugric theory. The prominent linguist and ethnographer, Pál Hunfalvy (1820-1891) was a proponent of the FinnoUgric theory. He was the first president of the Hungarian National Ethnographic Society established in 1889. In his Magyarország Ethnográphiája ['The Ethnography of Hungary'] of 1876 he discussed the Khazar issue and expressed doubts regarding whether the Khazars converted to Judaism and whether Jews came with Hungarians at the conquest. Hunfalvy's book used history and linguistic archeology as comparative methods to establish ethnographic claims and evidence. Kohn's book, A zsidók története Magyarországon a kezdetektöl a mohácsi vészig ['The History of the Jews in Hungary from the Beginning Until the Battle of Mohács'] is effectively an answer to Hunfalvy. Kohn's writing embodies the Neolog response to challenges to the Khazar connection theory and aims to place Hungarian Jews firmly within Hungarian history through the Khazars, both religiously and ethnically. In his work, Kohn addressed the same issues discussed by Hungarian scholars like Hunfalvy, by focusing on the origin of the Hungarians in Asia, the mixture of different peoples in the Orient prior to Hungarian migration 
Réthelyi, Mari. "Hungarian Jewish Stories of Origin: Samuel Kohn, the Khazar Connection and the Conquest of Hungary." Hungarian Cultural Studies. e-Journal of the American Hungarian Educators Association, Volume 14 (2021): http://ahea.pitt.edu DOI: 10.5195/ahea.2021.427

to the Carpathian Basin, and an ethnographic look at the conquest of Hungary. Like them, Kohn offered evidence of a geographic point of origin and explored historical socio-cultural interaction, yet had a distinct apologetic goal: to argue for the acceptance of Jews and the Jewish religion in Hungarian society by proving common ethnic and/or religious origins of Jewish and non-Jewish Hungarians. The geographic proximity between ethnic Hungarians and Khazars in ancient times was crucial to his argument and he used this factor to extrapolate different variants of the Khazar ancestry hypothesis.

Kohn's style of exposition was necessarily subtle and somewhat vague since the aim was not to provide a final verdict about the Hungarian past under the Khazars, but rather to indicate historical possibilities and leave some broadcasted notions tacit and open to interpretation. He uses many varieties of accounts as these arguments were not consistent with regard to where modern Hungarian Jews originated, what their relationship was to the Khazars and who conquered the land. However, a persistent implicit acknowledgment for apologetic ends was that, although Hungarians subsequently converted to Christianity, some did not abandon the Jewish faith. Furthermore, since they originally intermarried in the Khazar Empire, all Hungarians (regardless of religion) were of the same ethnic origin. Although often referenced as a possibility or even likelihood, the common origin claim was not rigorously or comprehensively explored anywhere in the text. The intent was to lay the groundwork for establishing various historically significant relationships between Jews and Hungarians. Below I examine the complex particularities of Kohn's views in more detail.

\section{Pre-Conquest Religious or Ethnic Connection between Jews and Hungarians}

Kohn presented two different accounts of how the Khazars united the Jewish and Hungarian peoples into one nation. In the first narrative, he hypothesizes that all ethnic Hungarians converted to Judaism during the Khazar era and had a common religion, even though they initially did not share a common ethnicity. In the second narrative, he asserts that Hungarians and Jews had a common ethnicity originating in the Khazar Empire, even if there was not a historical period of religious homogeneity. In other words, the question he posed was whether Hungarians and Jews were divided or united by ethnicity and/or by religion. Kohn claimed that they were united by one if not both and arrived at his conclusions by weaving together a combination of these two historical possibilities. He does not specify the chronological of the different accounts he presents, which allows them to have been both true at different periods in Hungarian history. Due to Kohn's status and position, his view became the dominant interpretation regarding the origins of Hungarian Jews in the Neolog community.

The basic premise of his first theory, the one of common religion, was that the Hungarians and the Khazars were two distinct ethnic groups (nép), but that for a period they shared the same religion because the Khazars converted the Hungarians to Judaism when they lived together in Lebédia, a Hungarian settlement near the Ural Mountains of Eastern Europe. This Khazar theory was summarized in the following narrative: "[T]he pagan Hungarians [had] already encountered Jews in Lebédia and they got to know the Jewish religion already when they resided with their Khazar allies" [A pogány magyarok tehát már Lebédiában lalálkoztak 
Réthelyi, Mari. "Hungarian Jewish Stories of Origin: Samuel Kohn, the Khazar Connection and the Conquest of Hungary." Hungarian Cultural Studies. e-Journal of the American Hungarian Educators Association, Volume 14 (2021): http://ahea.pitt.edu DOI: 10.5195/ahea.2021.427

zsidókkal, és a zsidó vallással már Kozár szövetségeseiknél megismerkedtek] (Kohn 1884:3). ${ }^{1}$ Kohn continues to state that "even the scientific world, and even our recent domestic historians, all acknowledge that they converted to the Jewish religion in the second part of the eighth century" [Mint az összes tudományos világ és ujabb hazai történetíróink is egytöl egyig elismerik, a VIII. század második felében zsidó hitre tértek] (Kohn 1884: 4). The Khazars' proselytization of the Jewish faith expanded geographically when the Kievan Rus defeated the Khazars and the Khazars, many of whom were Jewish, fled to neighboring countries. Kohn ponders the following in connection with the possible influence of these events:

If we take into account this wide-reaching and long-lasting, Jewish religious movement that originated with the Khazars, and consider that the Khazars wanted to convert even their enemies, the Rus, who were of a different race and lived far from the Khazars, and that the Khazars actually did convert some other peoples, then it is unlikely that they would not have tried to do the same with their neighbors, the Hungarians, who were also their allies and kin in terms of race

[Ha most tekintettel vagyuk e messzeterjedö és tartós zsidóvallási mozgalomra, mely a kozároktól eredt, és szem elött tartjuk, hogy a kozárok a tölük távolabb esö, irányukban ellenséges s egészen más fajú oroszokat is meg akarták téríteni, és más népeket meg is térítettek: elképzelhetjük-e, hogy ugyanezt meg ne kísérették volna a töszomszédságukban lakó szövetséges és fajrokon magyaroknál is] (Kohn 1884: 7).

This idea of a historical common faith among Hungarians relies on the theory that Khazars were Jewish proselytizers and even attempted to convert their enemies. Therefore, they must have converted their allies, the Hungarians, even though they were a different people.

Note, however, that Kohn argues in the same sentence that the Hungarians were more not only allies, but also the racial kin of the Khazars. The racial connection sets the stage for the second possibility he presents - that Hungarians and Hungarian Jews were of the same nemzetiség ['ethnicity'] but maintained different religions historically. Kohn goes on to point out that the Khazars used intermarriage with other tribes as a way to proselytize. He states that as a result of intermarrying with the Hungarians in Lebédia, the Khazars and their long-time allies the Hungarians eventually became one ethnicity. The Khazars "married their sisters and daughters to the pagan Hungarian leaders...they tried by all means...to spread the Jewish religion among their neighbors" [növéreiket és leányaikat... a pogány Magyar vajdaknak nöül adni: de azért minden módon azon voltak...hogy a zsidó vallást a szomszéd népek közt terjesszék]'(Kohn 1884: 5). It is likely that some of the offspring of these intermarried families were Jewish because, as Kohn states,

How could there not be Jewish Khazars among the ones who joined the Hungarians? To this question the unbiased and fact-centered historian cannot say no. Because the origin, language and religion of the Jews are the same as those of the Hungarians. They are kin from the same tribe, who were Jewish by religion but not by nationality and tribal origins

${ }^{1}$ All translations are by the author. 
Réthelyi, Mari. "Hungarian Jewish Stories of Origin: Samuel Kohn, the Khazar Connection and the Conquest of Hungary." Hungarian Cultural Studies. e-Journal of the American Hungarian Educators Association, Volume 14 (2021): http://ahea.pitt.edu DOI: 10.5195/ahea.2021.427

[Akkor éppen azon kozárok közt, akik a magyarokhoz csatlakoztak, ne volna ily zsidóhituek? E kérdésre tárgyilagos s elfogulatlan történetíró alig fog nem-mel felelhetni...Mert a zsidó kozár származására, nyelvre és elöbbi vallására nézve, a magyarral egy eredetü, ennek egy törzsröl szakadt közeli rokona, tehát nem nemzetiségére vagy eredetére, hanem csak vallására nézve volt zsidó] (Kohn 1884:9).

That is, the Khazar Jews' ethnic origin was not 'Jewish,' meaning Semitic, only their religion was Jewish.

Here Kohn acknowledges the likelihood that, due to subsequent conversions to other religions, not all Hungarians remained Jewish in religion. Yet this circumstance did not alter their ethnic origin, which they still shared with Jewish Hungarians after converting. In Kohn's argument, the Khazars and Hungarians were only superficially religiously Jewish, so they easily gave up their Jewish religion. As he writes, "Their Jewish faith was not rooted deeply in their soul, but relied on appearance and was only superficial; as easily as they embraced the Jewish religion did they exchange it for the victorious Christianity" [mivel zsidó hitük aligha gyökerezett mélyen lelkükben, hanem nyilván csak némi külsöségekre szoritkozván, elég felszínes lehetett. Ugyanazzal a könnyüséggel, amelllyel azt felkarolták, késöbb nagy részben el is hagyták és felcserélték a diadalmas kereszténységgel] (Kohn 1884: 10). The essence of Kohn's two-pronged argument is that Jews (i.e., Jewish Khazars and their descendants) and ethnic Hungarians had their origins in the Khazar Empire where they formed a single nation. Although originally two separate tribes, as he describes in his first account, the Khazars converted some or all of the Hungarians to Judaism. His second account describes how their descendants became one unified ethnicity due to extensive intermarriage between the Hungarians and the Khazars, who themselves had previously converted to Judaism. Kohn acknowledges that after the establishment of Hungary and the state conversion to Christianity at the turn of the first millennium, the majority of Hungarians became Christians. However, some Hungarians remained Jewish, and, in Kohn's (and other Neologs') view, became modern day Hungarian Jews. Regardless of the religious differences that had arisen since the state conversion, Jewish and non-Jewish Hungarians still share the same ethnic origin as they did at the time of the Hungarian conquest. Kohn uses the names of Jews, Khazars, and Hungarians interchangeably to indicate that they were actually the same people. In other words, Jews are ethnic Hungarians: they have been one people since they began intermarrying with Khazars in the eighth century and conquered Hungary together. They also share religious ties due to having converted to Judaism in the Khazar Empire. Thus, Hungarians and Jews have constituted one nép ['people'] from the beginning. Whether Jewishness signifies a religious or ethnic affiliation, Kohn connected the two accounts as historical stages in order to show that both can be true.

\section{The Significance of Religious and Ethnic Pluralism During the Hungarian Conquest}

Whereas his first examination of Hungarian-Jewish religious and ethnic connection focuses on the period prior to the Hungarian conquest, the second part of Kohn's argument is founded upon the definition of the conquest as a nation-making event and analyzes the origin of the Jews present at the conquest by using Jewishness as an interchangeable, religious and ethnic marker. Kohn describes three distinct groups of Jews who participated in the conquest: 1) Jewish ethnic Hungarians (the descendants of Hungarians and Khazars who intermarried as described above); 2) the Jews who were already living in the Carpathian Basin at the time of the conquest; 
Réthelyi, Mari. "Hungarian Jewish Stories of Origin: Samuel Kohn, the Khazar Connection and the Conquest of Hungary." Hungarian Cultural Studies. e-Journal of the American Hungarian Educators Association, Volume 14 (2021): http://ahea.pitt.edu DOI: 10.5195/ahea.2021.427

3) the Kabars, a Jewish Khazar tribe who allied themselves with the Hungarian people but were ethnically distinct, if distantly related. In anticipation of criticism regarding the significance of the Jewish presence at the conquest, Kohn presents multiple ways in which Jews participated. His first claim builds upon stages one and two of his Khazar ancestry theory by focusing on the ethnic Hungarian descendants of the Khazars. While Kohn acknowledges that there were adherents to a variety of religions at the time of the conquest, he posits that at least some ethnic Hungarians whom the Khazars converted and then intermarried with in the Khazar Empire remained Jewish at the time of the conquest. Kohn points out that his Hungarian colleagues recognize the religious pluralism of the ancient Hungarians by stating that,

our most respected domestic historians in part directly and in part indirectly, but still firmly and clearly believed it to be true and state in agreement that different [religious] denominations could have existed among the Hungarians in their ancient settlements. As was the case among their blood-relative neighbors, the Khazars, different religions were also known among the Hungarians. Thus, obviously the teachings of the Jewish faith as well was widespread. It is impossible therefore that the Hungarians would not have known them

[Ezen állitást legtekintélyesebb hazai történetíróink is részint közvetetlenül, részint közvetve, de azért elég határozottan és világosan, igaznak vallják...egyhangúlag azt állítják, így a magyarok közt amaz ösibb székeikben ezen különbözö felekezetek létezhettek már; hogy mint kozár vérrokonaik és szomszédjaik, úgy a magyarok közt is e különféle vallási tanok ismerete - tehát világosan a zsidó vallási tanoké is-elterjedve volt...lehetetlen, hogy ismeretlenek maradtak volna a magyarok elött] (Kohn 1884: 7).

In this quote Kohn admits to the possibility that, even though Hungarians and Jews were of the same ethnicity descended from intermarried ancient Hungarians and Khazar Jews, some may never have converted to Judaism. Additionally, by the time of the conquest, some of those who had, may have converted to other religions. Irrespective of this point, Kohn underscores that ancient Hungarians were intimately acquainted with Judaism from their time in Lebédia. Even if not all ancient Hungarians were religiously Jewish at the time of the conquest, they were still one people with a shared lineage.

As a historian, Kohn had to address the preexisting scholarly argument that Jews have been present in the Carpathian Basin (called Pannonia by the Romans) since Roman times. In his second claim, he conceded that it is not possible to know whether all modern Hungarian Jews are of Khazar ancestry or not. Despite Kohn's belief in the Khazar ancestry theory, he did not associate all Hungarian Jews exclusively with the Orient, and indeed claimed that there were two kinds of Jews in Hungary: those who had already been living in the Carpathian Basin at the time of the conquest (and who, in terms of ethnic origin, were strangers to the Hungarians), and those who came with the conquering Hungarians (i.e., the offspring of intermarried, ancient ethnic Hungarians and Khazars). He stipulates, "However, this does not weaken the significance of the fact that some of the oldest Jewish elements of this country were among the conquering troops of Árpád [found], partially among the Hungarians themselves, [and] partially there were those who were Jewish by religion, together with the Jews who were discovered here by the conquering Hungarians" [Ez azonban nem gyengíti annak a ténynek a jelentöségét, hogy Árpád honszerzö hadai között, részint tán maguk a magyarok, részint pedig azok kozár bajtársai közt, olyanok is voltak akik a zsidóhitet vallották és az új hazában talált zsidók mellett Magyarország legrégibb 
Réthelyi, Mari. "Hungarian Jewish Stories of Origin: Samuel Kohn, the Khazar Connection and the Conquest of Hungary." Hungarian Cultural Studies. e-Journal of the American Hungarian Educators Association, Volume 14 (2021): http://ahea.pitt.edu DOI: 10.5195/ahea.2021.427

zsidó lakosságának zömét képezték] (Kohn 1884: 9). He points out that not all Hungarian Jews were of the same ethnicity, although there were those who were kin to the ethnic Hungarians due to intermarriage in the Khazar Empire. Nevertheless, they all belonged to the Hungarian nation because they were present at the time of the conquest.

It was the overriding intent of Kohn to have every part of his argument support his hypothesis that Hungarians and Jews were related to each other in substantive ways. To this end, Kohn argued that simply being present at one time and place demonstrated that the Jews who had already been living in the Carpathian Basin were willing participants in the conquest. This interpretation therefore implied that these Jewish inhabitants had welcomed and identified with the conquering Hungarians. In this approach, the nature of the posited relations is less important than their putative, assumed existence. In this vein, Kohn goes on to express that,

Although there is no direct evidence for this claim, the above listed circumstances seem so significant, and a great deal of data exists to support it indirectly, or at least very definitely, so we can clearly say it is true, even more so, because of a number of random and otherwise inexplicable historical facts, and even the first few centuries of Hungarian Jewish history could not be understood if we do not assume this hypothesis"

[E tétel, igaz, közvetlen adatokkal nem bizonyitható. De a fent jelzett idevágó körülmények annyira döntöek, és e tétel mellett annyi késöbbi adat tesz közvettett, de azért elég határozott tanúbízonyságott, hogy bátran igaznak fogadhatjuk, még pedig annyival inkább, minthogy több felötlös különben megmagyarázhatatlan történelmi tényt, de magának a magyarországi zsidók történetének elsöszázadait sem érthetjük meg, hacsak ebböl a feltevésböl nem indulunk ki] (Kohn 1884: 9).

Kohn openly acknowledged that he relied on a hypothesis, not established historical facts, for his argument. However, in his view, the known facts only make sense through this hypothesis and thus render the hypothesis true.

Kohn returned to an examination of Jewish conquerors by focusing on the role of the Kabar (or zsiday, meaning Jewish) tribe in his third claim about the origin of Jews present at the conquest. He claims that the Kabars were a Jewish Khazar tribe who rebelled and allied themselves with the Hungarian tribes to conquer the Carpathian Basin. Because the Kabars were a distinct tribe from the Jewish Hungarians, this leg of his argument addressed those who were skeptical that Jewish Hungarians of Khazar descent had participated in the conquest. Even for those who did not accept the first two stages of Kohn's Khazar ancestry theory, the Kabar narrative reinforced the notion that Jews were present among the conquering forces. In Kohn's version of history, the Kabar tribe also had a leading role in the conquest. Kohn describes the Kabars as the Jewish Khazar tribe that fought alongside the Hungarian tribes, although they were only related distantly related through the Hungarians' Khazar ancestors. Although in this quote he does not refer to them by name, based on other sources it is known that the eighth Hungarian tribe refers to the Kabars. He recounts about the Kabars that "inner fights and strife occurred among the Khazars, [some of whom] then escaped to the defeated Hungarians and joined their seven tribes to become the eighth tribe" [a kozárok közt viszályok és belháborúk támadtak, minek következtében a legyözött magyarokhoz menekültek és hozzájuk csatlakozván a magyarok hét törzsét egy nyolcadikkal szaporították] (Kohn 1884: 8). Thus, the Kabars became a Hungarian tribe who "after they left the Khazars constituted the first core tribe of the Hungarians" [most tehát a kozároktól elpártolt kabarok a magyarok első törzsét képezik] Kohn 1884: 8). Moreover, 
Réthelyi, Mari. "Hungarian Jewish Stories of Origin: Samuel Kohn, the Khazar Connection and the Conquest of Hungary." Hungarian Cultural Studies. e-Journal of the American Hungarian Educators Association, Volume 14 (2021): http://ahea.pitt.edu DOI: 10.5195/ahea.2021.427

this founding tribe of the Hungarian nation was "powerful and valorous, [and] fought at the front-line of battles as the leading tribe" [Minthogy eröre és vitézségre kitünnek, a csatában elöl vívnak, mint elsö törzs] (Kohn 1884: 8).

The Kabar tribe became allies of the Hungarian tribes and, as good warriors, shouldered much of the burden during the conquest. That leading role earned them a right to the land, and so they were granted the same rights as the Hungarians who were pagan at that time. Kohn references that other historians recognize the Kabar participation in the conquest by saying, "when a group of Khazars called the Kabars allied themselves with the Hungarians, they joined the troops of Árpád and went with them to Pannonia. This is acknowledged as historical fact by all of our historians. Moreover, it was also certain that the conquest of the new homeland was in no small part due to their merit as well" [Dehogy a Kabarok a magyarokhoz csatlakoztak és Árpád hadait Pannoniába el is kísérték, azt összes tötrénetíróink történelmi ténynek ismerik el. Söt bizonyos az is, hogy az új haza megszerzése nem csekély részben az ö érdemük is volt] (Kohn 1884: 8).

Thus, if there was any doubt that descendants of ethnic Hungarians and Jewish Khazars formed one people, as Kohn hypothesizes in the first parts of his argument, he offers the possibility that the Kabars, a Khazar tribe with their own form of Judaism and distinct, if related, bloodline, could still have brought the Jewish religion to Hungary. The Kabars were considered to be an integral part of the Hungarian nation because of their role in the conquest. Additionally, Kohn writes that the Jewishness of the Kabars who participated in the conquest is proved by "an old Hungarian tale, [which held that] among the hundred and eight nations that made up the conquering Hungarian nation, there was a Jewish nation. This folklore appears to preserve the memory of the ancient Hungarian comrades of the Jewish faith" [Régi Magyar hagyomány szerint, ama száznyolc nemzetség közt, mely a honfoglaló Magyar népet alkotta, egy Zsiday nemzetség is volt. E hagyomány úgy látszik fenntartotta a régi magyarok zsidóhitü bajtársainak emlékét] (Kohn 1884: 9). Kohn reasons that we know the Kabars were religiously Jewish because he assumes that the etymology of zsidó ['Jew'], is derived from the zsiday ['Jewish'] nation, as the Kabars were also known. He highlights the ethnic ties between the Kabars and the other Hungarian tribes who participated in the conquest, asserting that they "did not differ in anything from their non-Jewish brothers" [nem-zsidó testvéreiktöl semmiben sem különböztek] (Kohn 1884: 10). Kohn claims that the presence of Jews at the founding of the Hungarian nation was unquestionable, due to the oral evidence of a Jewish (zsiday) nation among the invading forces. Fighting alongside one another in the conquest functioned to prove the national bond between Jewish Kabars and Hungarians of all faiths.

He emphasizes that the Jewish Kabars were there as active participants in the conquest itself, and co-governed with the ethnic Hungarians afterwards. When the Hungarians, "came to the kingdom of Attila, many Khazar tribes joined them and fought in front line with the conquerors, even if they were of the Jewish faith, they lived with their kin the Hungarians in peace. As siblings, they shared fortunes, both good and bad, military victories and failures, leadership and management of the country for hundreds of years" [Ezek Attila hajdani birodalma felé vonultak, több kozár törzs velök tartott, kik a honfolgalók élén harcoltak-ha zsidóhituek voltak is, vérreikkel a magyarokkal igen jól megférnek és bajban és örömben, harci dicsöségben és balsikerben, birtoklásba és az ország igazgatásában századokon át testvériesen osztozkodnak] (Kohn 1900: 4). 
Réthelyi, Mari. "Hungarian Jewish Stories of Origin: Samuel Kohn, the Khazar Connection and the Conquest of Hungary." Hungarian Cultural Studies. e-Journal of the American Hungarian Educators Association, Volume 14 (2021): http://ahea.pitt.edu DOI: 10.5195/ahea.2021.427

Kohn posits that the Kabars who were related to the Hungarians through the Hungarians' Khazar ancestors in Lebédia, conquered and then ruled the land together with non-Jewish Hungarians. The Kabars remained distinct from the non-Jewish Hungarians at the time of the conquest, but this distinction had been erased through intermarriage after the conquest. Kohn reemphasized the long common preconquest history to support his argument that both types of Khazar Jews (Hungarian Jews of Khazar descent and Kabars) were an organic part of the Hungarian nation. "The two blood-kin, offspring of the same nation, have long been in contact with each other and have developed an intimate relationship. The Khazars and the Hungarians who probably learned each other's languages that differed only in dialects, became close allies" [A két vérrokon, egy törzsröl szakadt nép közt, mely egymással már régóta érintkezésben állott, csakhamar a legbensőbb viszony fejlödött ki. A kozárok és a magyarok...kik valószínüleg csak szójárásilag különbözö nyelvüket egymástól eltanulták, szoros szövetséget kötöttek] (Kohn 1884:

3). Even if there was not one unified ethnic group of Hungarians who were the product of intermarriage between Hungarians and Khazars and had converted to Judaism, there was still this distinct group of Jews, the Kabars, who conquered Hungary together with the non-Jewish tribes. Therefore, the Kabar role in the conquest does not speak to an ethnic and religious unity between Hungarians and Jews, but to a national unity due to their participation in the founding of the nation through conquest. This argument acknowledges the possibility of ethnic and religious pluralism at the time of the conquest, while still highlighting the historical contribution of Jews to the nation. In summary, Kohn's two-account theory exploring ethnic and religious connection between ancient Hungarians and Khazars incorporates three claims about Jewish origins, such as the Khazar religious conversion to Judaism in Lebédia, creating a unified ethnicity through intermarriage with Hungarians, and finally, the conquest of Hungary alongside other non-Jewish and Jewish tribes such as the Pannonian Jews and the Kabars, who became integrated into the Hungarian nation post-conquest. Although the many aspects of his Khazar ancestry theory are contentious from a historical perspective, this narrative was instrumental in pushing for widespread acceptance of Jews into modern Hungarian society by appealing to nationalist concepts of shared origins in the East.

\section{Conclusion}

Hungarian nationalism compelled historians to create narratives of the past that suited contemporary nationalist needs, while the romantic movement of the late nineteenth century enabled them to invent whichever past they wished for. The 1896 millennium celebration of the Hungarian conquest of the Carpathian Basin placed the conquest at the center of national identity building. In response, scholars focused on the history of the Hungarian people leading up to and including the time of the conquest. This excavation of the Hungarian past led to the study of their Asian and nomadic roots. The Eastern origins of Hungarians became the point of entrance for Neolog Jews into the Hungarian Oriental origin discourses. I argued that Kohn, as a leading Neolog scholarly authority on the Khazar theory, combined two theories of connection between the Hungarians and the Jews via the Khazars: by ethnicity and by religion. By presenting multiple possibilities of the ethno-religious makeup of ancient Hungarians, he demonstrates that at some point in their history, Hungarians and Jews shared an ethnicity and religion, either fully or partially. Another significant issue that Kohn examined was who was physically present at the conquest. This is equally significant for both Jewish and non-Jewish Hungarians because presence at the conquest earned one the right to live in the land as a part of the nation. TO this end, Kohn presented three historical possibilities about Jewish origins: First, Khazar Jews 
Réthelyi, Mari. "Hungarian Jewish Stories of Origin: Samuel Kohn, the Khazar Connection and the Conquest of Hungary." Hungarian Cultural Studies. e-Journal of the American Hungarian Educators Association, Volume 14 (2021): http://ahea.pitt.edu DOI: 10.5195/ahea.2021.427

converted (possibly most of the) Hungarians to Judaism in Lebedia, and, thus, they historically shared a religion. Second, Khazar Jews intermarried with ethnic Hungarians and became one people, even if not all converted to Judaism and some of those who did subsequently converted to Christianity. Third, as a consequence of long common history multiple Jewish tribes were present at the conquest: such as, the Pannonian Jews, the Kabars and descendants of the Jewish Khazars who intermarried with the non-Jewish Hungarian tribes, constituting one mix of people at the conquest. Kohn states that these 'Hungarians' were ethnically united but later became divided by faith after the conquest when a century later the majority of the descendants of the conquering Hungarians converted to Christianity. Next, he discusses the Jews who had been living in the region of Hungary since before the conquest, and lastly, he presents evidence that an independent Jewish Khazar tribe, the Kabar, allied and traveled with the Hungarian tribes from Lebédia and conquered Hungary together with them. Kohn insists that any and all of these historical accounts should grant modern Jews the same rights as those descended from other people who were present during the conquest.

The ultimate goal of the argument that Kohn presented was that in the past, there were periods where no ethnic barriers or religious differences existed between Jewish and non-Jewish Hungarians, and therefore nothing should prevent them from living together in mutual respect in the present. He goes so far as to say that the present union is in fact a reunion, since Hungarians and Jews were once one people (Konrád 2018: 56). As a final rebuttal against those who doubt this point, Kohn asserts that having conquered the land together gives Jews the right of residence in Hungary irrespective of whether Jews and Hungarians have the same ethnic origins or practiced Judaism together at one point. Kohn's articulation of the Khazar Jewish ancestry argument was influential because it provided a stage to argue for Jewish apologetics by stating that modern Hungarian Jews were compatible with non-Jewish Hungarians due to their shared ancestry and religion dating back to the Khazar Empire just as their joint participation in the conquest of Hungary gave them equal rights to live in the land. Among the various historical possibilities that Kohn describes, Judaism was always a religious denomination of ancient ethnic Hungarians. Additionally, the Kabars who fought alongside Hungarians at the conquest and later intermarried with them were also Jewish. Kohn reasons that anti-Semitism is baseless in Hungary because the history of Hungarian Jews is separate from those in other countries. That is, their histories are inextricably woven together because Hungarian Jews and non-Jewish Hungarians have been united since antiquity and conquered Hungary together. The joint conquest of the land is the lynchpin of Kohn's theory. Even if the Khazar theory might allow other Eastern European Jews to claim non-Semitic descent, in Kohn's argument, what cemented Jews as part of the nation was their presence at the conquest - the pivotal event that founded the Hungarian nation-state. This criterion allows Kohn to view the Jews who had been living in preconquest Hungary as much a part of the nation as those who participated in the conquest, even if these Jews did not come from the Khazar Kingdom and had no ethnic ties to Hungarians. Ultimately, his nationalist understanding of this historical event proves more inclusive than his ethno-religious historical theories, but they work in tandem to assert the undeniable presence of Jews among the ancient Hungarians. No matter how unfavorably Kohn's scholarly views were received, and how politically motivated and ideologically loaded the Khazar ancestry theory was, this theory became deeply rooted within Neolog Jewry who welcomed its message of ethnic and historical religious unity between Jews and Hungarians. 
Réthelyi, Mari. "Hungarian Jewish Stories of Origin: Samuel Kohn, the Khazar Connection and the Conquest of Hungary." Hungarian Cultural Studies. e-Journal of the American Hungarian Educators Association, Volume 14 (2021): http://ahea.pitt.edu DOI: 10.5195/ahea.2021.427

\section{Works Cited}

Brook, Kevin. 2003. “The Origins of East European Jews.” Russian History, 30.1: 1-22.

Büchler, Sándor. 1901. A zsidók története Budapesten a legrégebbi időktől 1867-ig ['The History of the Jews in Budapest Since the Beginning to 1867']. Budapest: IMIT.

Gerő, András. 2007. Imagined History. New York: Columbia UP.

Golden, Peter B. 2007. "Khazar Studies: Achievements and Perspectives." The World of the Khazars, Eds. Peter Golden, Haggai Ben-Shammai, András Róna-Tas, Leiden: Brill.

Gyurgyák, János. 2007. Ezzé lett Magyar hazátok ['This Became of Your Hungarian Home’]. Budapest: Osiris.

Hunfalvy, Pál. 1876. Magyarország ethnographiája ['The Ethnography of Hungary']. Budapest: M. Tud. Akadémia Könyvkiadó-Hivatala.

Kohn, Sámuel. 1884. “A honfoglaló magyarok és a zsidók” ['The Conquering Hungarians and the Jews']. Magyar Zsidó Szemle ['Hungarian Jewish Review'], 3-10.

Kohn, Samuel. 1900. “A kozárokrol” ['About the Khazars']. Egyenlöség ['Equality’], December 9, 4-5.

Kohn, Sámuel. 1884. A zsidók története Magyarországon a kezdetektől a mohácsi vészig ['The History of the Jews in Hungary from the Beginning till the Battle of Mohács']. Budapest: Atheneum.

Kohn, Sámuel. 1881. Héber kútforrasok és adatok Magyarország történetehez ['Hebrew Sources and Additions to the History of Hungary']. Budapest: Athenaum.

Kohn, Sámuel. 1896. “Zsidó történelmi emlékek különös tekintettel Magyarországra” ['The Jewish Historical Monuments in Hungary']. IMIT 2.1: 52-62.

Koestler, Arthur. 1976. The Thirteenth Tribe. Hutchinson.

Konrád, Miklós. 2018. "Narrating the Hungarian-Jewish National Past: The "Khazar Theory" and the Integrationist Jewish Scientific Discourse." Cultural Nationalism in a FinnishHungarian Historical Context, edited by Gábor Gyáni and Anssi Halmesvirta, Budapest: MTA Bölcsészettudományi Kutatóközpont Történettudományi Intézet, 49-61.

Konrád, Miklós. 2016. "Zsidók magyar nemzete. A nemzeti múlt és a zsidó múlt tudományos ábrázolása, különös tekintettel a kazárelméletre" [The Hungarian Nation of the Jews. The Academic Description of the National Past and Jewish Past with Emphasis on the Khazar Theory']. Századok ['Centuries'], 3: 631-665.

Lafferton, Emese. 2007. "Magyar Moustache." Studies in History and Philosophy of Science 38.4: 706-32.

Nagy, Gyula. 1884. "A zsidók története Magyarországon” ['The History of the Jews in Hungary']. Századok ['Centuries'], 894-5.

Róna-Tas, András. 2007. "The Khazars and the Magyars." The World of the Khazars, edited by Peter Golden, Haggai Ben-Shammai, András Róna-Tas. Brill, 269-278.

Róna-Tas, András. 1995. A magyarság korai története ['The Early History of the Hungarians']. Szeged, 352-5.

Schweitzer, József. 1990. “Kohn Sámuel és a magyar zsidó történetírás két évszázada” ['Samuel Kohn and the Two Centuries of Hungarian Jewish Historiography'], Héber kútforrások és adatok Magyarország történetéhez ['Hebrew Sources and Data Towards the History of Hungary'], Kohn Sámuel. Budapest, i-xi.

Schweitzer, József. 2007. 'Uram nyisd meg ajkamat' Válogatott tanulmanyok és esszék ['God Open My Lips' Selected Studies and Essays']. Budapest: Universitas.

Shear, Adam. 2008. The Kuzari and the Shaping of Jewish Identity, 1167-1900. Cambridge UP. 